\title{
The Impact of Hopscotch Game towards the Growth of Kinesthetic Intelligence on 3-4 Year Old Children
}

\author{
Khusnul Laely, Dede Yudi \\ Lecturers at Universitas Muhammadiyah Magelang
}

\section{ABSTRACT}

This research aims to understand the impact of traditional game hopscotch towards the growth of kinesthetic intelligence on children enrolled at PAUD ALIF Kalinegoro, Kecamatan Mertoyudan, Kabupaten Magelang. The research employs experimental research design with One Group Pre-Postest Design. The experiment is conducted to one group without comparison group by using initial and final measurement. The variables in this research include children within 3-4 age group, amounting to 15 children enrolled at PAUD ALIF Kecamatan Mertoyudan Kabupaten Magelang. The samples are acquired using Total Sampling technique. The method for data collection is by using observation sheet and work method. The data analysis technique used is Wilcoxon Signed Rank Test with the help of computer program SPSS for Windows version 19.00.

The results find asymp.sig. column (2-tailed)/asymptotic significance for two-tailed test is 0,001 . Since the studied case is one-tailed test, the acquired probability is $0.001 / 2=0.0005$. Based on this data, the probability is that $0.05(0.0005<0.05)$, in which Ho is rejected, or in other words, there is a difference of kinesthetic intelligence on the initial and final measurement after the implementation of learning activity through traditional game hopscotch.

\section{KEY WORDS}

kinesthetic intelligence of children, hopscotch traditional game

\section{CORRESPONDING AUTHOR:}

email: khusnullaely@rocketmail.com

Manuscript submitted June 28, 2018; accepted Agustus 18,

2018.
Copyright: (C2018 This is an open access article under the terms of the Creative Commons Attribution License, which permits unrestricted use, distribution, and reproduction in any medium, provided the original author and source are credited.

\section{INTRODUCTION}

Recently, traditional game activities based on local wisdom has started to disappear by the existence of modern games that tend to be instant and individualistic. Apparently, traditional games are strongly related to the values of ethics, moral, and culture of its supporting society. Furthermore, this game model could stimulate plural intelligence, stimulate children's five senses system, ability to acquire information, train the ability and thinking process and to understand various regulations.

Furthermore, the government attempts to promote these traditional games through policies of child-friendly cities that aims to integrate development resources as the effort to fulfil children's rights. Education for all is 
one principle to achieve child-friendly city needs to be reviewed and addressed, which is by applying stilts traditional game using coconut shells to optimize children's kinesthetic intelligence. Such activities are hoped to help the government program and optimize kinesthetic intelligence in various levels of education.

Based on the observation conducted at PAUD ALIF Kec. Mertoyudan Kab. Magelang, the children's kinesthetic intelligence is still considered as low. Children tend to avoid coordinated body movement to exercise flexibility, balance, and agility, unwilling to perform coordination movement of feethands-head, unwilling to join game activities with rules, and unwilling to use their right and left hands.

On the other hand, traditional games such as hopscotch (engklek) at PAUD ALIF Kec. Mertoyudan Kab. Magelang are seldom used. In fact, this game is perfect to be introduced on early childhood, and it has many benefits, such as the development of kinesthetic intelligence.

Starting from the problem above, the researchers are interested in conducting an experimental research entitled The Impact of Hopscotch Game towards the Growth of Kinesthetic Intelligence of Children at PAUD ALIF Kecamatan Mertoyudan Kabupaten Magelang.

\section{Development Of Children's Kinesthetic Intelligence}

Amstrong (2002:3) believed that kinesthetic intelligence or physical intelligence is a form of intelligence, in which when one is able to dexterously use their body organs to do certain movements such as running, dancing, building objects, creating artworks and/or handcrafts.

Physical intelligence is the intelligence in performing decent movements such as in running, dancing, creating artworks. Some people who are talented in their physical activities and skilled in using their hands do not realize that they show high level of intelligence. Program materials in school curriculum that could help in developing physical intelligence include pantomime, dancing, and body movement (Kemdiknas, 2010, p. 12).

Campbell, Campbell and Dickinson (2002, pp. 77-96) explained that the purpose of program materials in a curriculum to enhance children's physical intelligence include several physical activities, various sports, modelling, ballroom dancing, dancing, and body language. Sujiono and Sujiono (2004, pp. 290292) described several ways to stimulate children's physical intelligence; they are:

a. Dancing. Children love music and dance. In order to enhance this physical intelligence, children can be invited to dance together because dance requires balance, alignment between body movements, power, and muscle flexibility

b. Role playing/drama. Through this activity, children's physical intelligence could also be encouraged. This activity requires children to use their body according to their roles, how they should have suitable facial expression, including their hands movement. Their ability to socialize could 


\section{ECRJ}

also improve because it requires them to cooperate with other people.

c. Physical skills training. Various physical training could help improving children's motoric skills, and of course this training could be adjusted to children's age. For example, walking on a floating board. This activity could be done when children are 34 years old. In addition to exercising their muscle strength, this activity could also train their balance

d. Sports. Various sports could also help improving health and growth. Sports should be adjusted to children's motoric development such as swimming, mini soccer, tennis, badminton, or gymnastic. Basically, all sports could improve physical intelligence by considering the fact that sports do use several body organs at the same time.

Some indicators of achievement level for physical development based on the Regulations of National Ministry of Education No. 58 (2009, p. 10) for 5/6-year-old children include: ability to perform coordinated body movements to train flexibility, balance, and agility; perform coordinated movements of feet-hands-head; perform physical games with rules; and ability to skillfully use both left and right hands.

\section{Hopscotch Game}

Hopscotch (engklek) traditional game is often referred as Sunda Manda traditional game. Engklek or Sunda Manda is a form of traditional game that is popular among children in Indonesia and is played by children in the past, and even now hopscotch is also popular among youths. Sondah or engklek is a simple traditional game, to play this game, players only need a chalk to draw eight squares on the ground that would serve as the playground (Wulandari, 2015, p. 4)

Hopscotch traditional game or commonly known as sunda manda is believed to be originally named as 'Zondag Maandag' from Dutch language. Thus, based on its history, hopscotch was brought to Indonesia by the Dutch during its colonization. Sunda manda that can also be called éngklék, téklék, ingkling, sundamanda/sundah-mandah, jlong jling, lempeng, or dampu is traditional children game popular in Indonesia, especially for rural community (Nindi, 2013, p. 1).

Hopscotch is usually played by children, from two to five players. Each player will jump with one foot on each square, which is previously drawn on the ground. To play, each player should have their own player token such as a broken tile or roof tile, which is also referred as kreweng. On each play, player places their kreweng on the drawn square by throwing from the start line. Players should not step on the square where they place the token, so they could only hop on the empty squares by using one foot.

Player who succeeds in finishing one round has the right to choose one square as their "sawah" or post, in which the owner could step on their post with two feet, while other players are not allowed to step on the square. Player with the highest number of post wins the game.

The picture for hopscotch game is already available in the school ground so that the students can play the game anytime. The 
students are more excited to play this game at the school ground. This game is considered as outdoor type of game, and the procedures to play this game are as follows:

a. Before we start the game, we need to draw squares on the ground. We draw five squares adjacent to each other in vertical line, and we add two more squares on each side.

b. Each player hops with one foot on each drawn squares. In order to play, each player should have their own token or kereweng, such as a broken piece of tile or roof tile or flat stone

c. Kreweng/token is thrown to one square on the ground, and the player could not step on the square with tokens. Thus, each player should hop on the square with one foot surrounding the available squares. While throwing the token, it cannot fall outside the drawn square, if it happens, the player is eliminated and replaced by the next player.

d. Player who finishes one round throws his token by turning his back from the hopscotch ground, if he can throw it on the square, the square becomes his "sawah" or post, which means that the owner could step on the square with two feet, while the other players could not step on it.

e. Player with the highest number of sawah or post becomes the winner.

The motivation or driving force to become winner on this game is pride, and becomes smart kid for winning the game and able to acquire most numbers of post. This predicate encourages the students to play to win and compete in the game. In addition to the children's nature to compete for winning the game. In this game, the player with the highest number of post or sawah becomes the winner. Hopscotch traditional game can encourage children to improve their skills and becomes more disciplined. Until today, hopscotch game still can be found in various traditional events, celebration of Independence Day, or in various competition.

The tools used in Sondah game are easy to find. To make the square lines depends on where we play the game. If it is outside the house: road in front of the house (chalk), asphalt road (chalk), and on the ground (make lines using wood or any object that can be used to make lines). If it is at home: garage (using masking tape) and inside the house (using Puzzle carpet) (Wulandari, 2015, p. 5).

In the midst of the popularity of electronic games and various department stores equipped with game centers also slowly banish traditional games. This is not the case for children in the region of Kabupaten Magelang, they still play this game as a part of effort to preserve culture and would not let this game erased by the time.

\section{The Impact Of Hopscotch Towards Kinesthetic Intelligence}

The use of game plays an important role in achieving learning purpose. The success of learning process is highly determined by teacher's creativity in arranging learning process as a form of game or playful activity. Playing is an activity done by children all day long because for children, life is to play and to play is life (Mayesti, 1990:196-197). Early age children do not differentiate between playing, 
studying, and working. In general, children enjoy playing and will keep doing it wherever they are and whenever they have the opportunity to.

However, real life practice shows that in the development of intelligence, especially of kinesthetic intelligence, teachers only invite students to play catch continuously, which will make them bored of similar activity. Moreover, children's interest today is only to play in front of computer.

Through hopscotch, children's kinesthetic intelligence will improve and this game also invites children to play outdoor, which will bring different spirit from the usual activity and children will be more fascinated. Children's interest and fascination towards hopscotch will improve the children's kinesthetic intelligence.

\section{RESEARCH METHOD}

This research used experimental research design with One Group Pre-Postest Design. This experiment was conducted towards one group without comparison group. Experimental group on this research was given treatment for a certain period of time and would be measured again to acquire the research result. This design can be described in the following:

Table 1

Experimental Research Design One Group Pre-Postest Design

\begin{tabular}{|l|l|l|}
\hline $\mathrm{T}_{1}$ & $\mathrm{X}$ & $\mathrm{T}_{2}$ \\
\hline
\end{tabular}

Explanation:

T1 : Initial measurement of kinesthetic intelligence before implementing 'Egrang' game made of coconut shells
$X$ : Treatment, in the form of 'Egrang' game made of coconut shells

T2 : Final measurement of kinesthetic intelligence after implementing 'Egrang' game made of coconut shells

The variable in this research was children in the age group between 3-4 years old enrolled at PAUD ALIF, academic year 2015/2016, amounting to 15 students. The samples were acquired through Total Sampling. The data collection method was using observation sheet and work method. The data analysis technique used was Wilcoxon Signed Rank Test with the help of SPSS program for Windows version 19.00.

\section{RESULTS AND DISCUSSION}

The initial measurement of children's kinesthetic intelligence was conducted on March 16, 23, 30, 2016 at Bustaanul Athfaal Aisyiah Kalinegoro, Kecamatan Mertoyudan, Kabupaten Magelang, which amounted to 15 children, with 60 minutes duration for each student. The initial measurement of kinesthetic intelligence aimed to understand the extent of children's kinesthetic intelligence before treatment or implementing hopscotch game on their lesson. During the initial measurement, children's kinesthetic intelligence was measured by the children's ability to walk along rice field with balance, walk above the floating board with balance, to have good coordination between left and right hands, to have good coordination between right and left foot, hop on one foot for $10 \mathrm{~m}$ without falling, hop on one foot for $20 \mathrm{~m}$ without falling, keep left foot and right foot from touching the ground while hopping. The 
observation result of the initial measurement can be seen in Table 2 and the full result on the initial measurement of kinesthetic intelligence of the subjects $(\mathrm{N}=15)$ is also included in the following section. The following will be the complete data of the initial measurement:

Table 2

Description of Initial Measurement of Kinesthetic Intelligence of 3/4-year-old Children

\begin{tabular}{|c|c|c|c|}
\hline $\mathrm{N}$ & Minimum & Maximum & Mean \\
\hline 15 & 8 & 14 & 11,6 \\
\hline
\end{tabular}

Based on Table 2, it is known that the 15 research subjects had low kinesthetic intelligence. According to the initial measurement, it can be seen that the minimum value only reaches 8 , and the maximum value is 14 , with the mean of 11.6.

The final measurement of children's kinesthetic intelligence was conducted on May 7 and 14, 2016 PAUD ALIF Kecamatan Mertoyudan, Kabupaten Magelang, amounting to 15 children with 60 minutes duration for each student.

The final measurement of children's kinesthetic intelligence aimed to understand the result of treatment after the implementation of hopscotch traditional game in the lesson. During the final measurement, the aspects to be observed include ability to walk through the rice field with balance, walk on the floating board with balance, have good coordination between right and left foot, have good coordination between left and right hand, hop on one foot for $10 \mathrm{~m}$ without falling, hop on one foot for
$20 \mathrm{~m}$ without falling, keep left foot and right foot from touching the ground while hopping. The result of final measurement can be seen in Table 3 and the complete result of final measurement of all subjects $(N=15)$ is included in the following section:

Table 3

Description of Final Measurement of Children's Kinesthetic Intelligence

\begin{tabular}{|c|c|c|c|}
\hline $\mathrm{N}$ & Minimum & Maximum & Mean \\
\hline 15 & 8 & 27 & 23 \\
\hline
\end{tabular}

The result of final measurement in Table 3 shows that after the implementation of hopscotch as lesson, the kinesthetic intelligence of 15 research subjects had significant increase. This can be seen through the minimum value of 8 , the maximum value of 27 , with the mean value of 23 .

The research results find asymp.sig. column (2-tailed)/asymptotic significance for two-tailed test is 0.001 . Since the case is onetailed test, the probability found is $0.001 / 2=$ 0.0005, in which it is found that the probability that $0.05 \quad(0.0005<0.05)$. Therefore, Ho is rejected, or there is a difference between children's kinesthetic intelligence during the initial and final measurement after the implementation of hopscotch traditional game as part of learning activity. Based on this series of test, the hypothesis that "Hopscotch traditional game influences the development of children's mathematical ability" is proven to be correct.

Various determining factors influencing children's kinesthetic intelligence include learning process at school, and teachers' roles. One learning practice that is proven to 
be successful in boosting this intelligence is hopscotch traditional game.

The research results show that there is an increase of children's kinesthetic intelligence after the implementation of hopscotch as learning activity. It was started from the moment where all the research subjects had low kinesthetic intelligence and they were given learning activity in the form of hopscotch game, and the researchers conducted the final measurement to make comparison between the initial and final condition. The following section will thoroughly explain the initial and final condition of the research subjects after implementing hopscotch game as learning activity.

The research result using hopscotch traditional game as learning activity could improve children's kinesthetic intelligence. During the learning activities using hopscotch game with procedures, the students were asked to walk along rice field with balance, walk above the floating board with balance, to have good coordination between left and right hands, to have good coordination between right and left foot, hop on one foot for $10 \mathrm{~m}$ without falling, hop on one foot for $20 \mathrm{~m}$ without falling, keep left foot and right foot from touching the ground while hopping.

The research results believed that hopscotch traditional game can improve children's motoric ability. This is in accordance with study conducted by Campbell, Campbell and Dickinson (2002, pp. 77-96) that the purpose of program material in school curriculum is to improve physical intelligence, such as various physical activities, various sports, modelling, ballroom dancing, dancing, and body language. In its operational level, hopscotch game could stimulate various physical activities.

\section{CONCLUSION}

Traditional game plays important role in learning process especially in developing students' kinesthetic intelligence. Hopscotch traditional game used as the object in this research is proven to have significant impact on the development of children's kinesthetic intelligence. The action on students at Bustaanul Athfaal Aisyiah Kalinegoro Kecamatan Mertoyudan Kabupaten shows significant data on children's kinesthetic intelligence after the school implements learning with hopscotch traditional game.

\section{REFERENCES}

Aisya. (2011). Permainan engklek. https://aisyahinsani.wordpress.com/2011/02/ 27/permainanengklek.

Beaty, J. J. (2013). Observasi perkembangan anak usia dini. Jakarta: Kencana Prenada Media Group.

Bee, H. (1998). The growing child. New York: Longman.

Papalia, D.E., et al. (2008). Human development. Jakarta: Kencana Prenada Media Group.

Sanjaya, W. (2006). Strategi pembelajaran berorientasi standar proses pendidikan. Jakarta: Kencana Prenada Media. 
Santoso, S. (2009). Panduan lengkap menguasai statistik dengan SPSS 17. Jakarta: PT Elex Media Komputindo.

Sujiono, Y. N. (2010). Bermain kreatif berbasis kecerdasan jamak. Jakarta: Indeks

Wulandari, D. (2015). Permainan tradisional sondah. http://deawulandari.blog.upi.edu/2015/10/21 /makalah-permainan-tradisional-sondah 